\title{
PEMBATALAN PERJANJIAN BANGUN GUNA SERAH (BUILD OPERATE TRANSFER/BOT) ANTARA PEMERINTAH DAERAH KOTA BOGOR DENGAN PIHAK SWASTA (PT PANCAKARYA GRAHATAMA INDONESIA) DITINJAU DARI SUDUT KITAB UNDANG-UNDANG HUKUM PERDATA
}

\section{Lorenzo Marco}

(Mahasiswa Fakultas Hukum Universitas Tarumanagara)

(Email: lorenzo.marco.lm@gmail.com)

\section{Gunawan Djajaputra}

\author{
(Corresponding Author)
}

(Dosen Fakultas Hukum Universitas Tarumanagara, Meraih Sarjana Hukum dari Fakultas Hukum Universitas Indonesia, Magister Hukum dari Fakultas Hukum Universitas Indonesia, Doktor Hukum dari Fakultas Hukum Universitas Indonesia)

(Email: gunawand@fh.untar.ac.id)

\begin{abstract}
The BOT (Build Operate Transfer) Agreement between Bogor Municipal Government and PT Pancakarya Grahatama Indonesia is an agreement to optimize Baranangsiang terminal assets as stated in the agreement Number: 601 / Perj.418-BPKAD / 2012 / Number: 005 / PGI / DIR / $V I / 2012$. Until now, the agreement of both parties has not been able to be considered because of the change of authority of the terminal which formerly the authority of the City Government of Bogor to switch to the Central Government, resulting problems Whether the Government / Mayor Bogor can cancel the unilateral agreement BOT in the construction of Terminal Baranangsiang viewed from the point Civil Code? The research method used is normative legal research method supported by interview and field data. Based on the analysis that the BOT agreement between Bogor City Government and PT Pancakarya Grahatama is a valid and binding agreement between both parties and can not be canceled unilaterally by Bogor City Government, although there are new regulations that change the authority of terminal A Baranangsiang become the authority of Central Government. The Agreement may be canceled if it violates Article 1320 of the Criminal Code or violates the subjective and objective terms of the validity of the agreement. When the agreement is mutually agreed upon by both parties, the agreement must continue and act as a binding law as regulated in Article 1338 of the Criminal Code. Bogor City Government should immediately provide certainty to the PT Pancakarya Grahatama Indonesia for Baranangsiang terminal revitalization project can be immediately realized and need a revision (adedendum) agreement between the Government of Bogor City with PT Pancakarya Grahatama Indonesia related to changes in authority of terminal A Baranangsiang between PT. PGI with the Central Government.
\end{abstract}

Keywords:Agreement, BOT, Baranangsiang Terminal, Bogor City Government, Private 


\section{PENDAHULUAN}

\section{A. Latar Belakang}

Pembangunan sarana dan prasarana memiliki peran yang sangat penting dalam mendukung aktivitas ekonomi suatu daerah. Pemerintah Kota Bogor merupakan salah satu kota yang sedang giat-giatnya membangun. Salah satu pembangunan yang cukup vital untuk mendukung laju ekonomi adalah pembangunan revitalisasi terminal kelas A Baranangsiang.

Membangun sarana dan prasarana dalam bentuk terminal membutuhkan biaya yang tidak sedikit dan rasanya pemerintah Kota Bogor memiliki kemampuan terbatas untuk membiayai semuanya sehingga dibutuhkan kerjasama dengan pihak swasta untuk mewujudkan jalannya pembangunan sarana dan prasarana tersebut. Pada umumnya, bentuk kerjasama antara pemerintah dengan pihak swasta dituangkan dalam bentuk perjanjianlsistem Bangun Guna serah (Build Operate and Transferl BOT).

Sistem BOT adalah bentuk perjanjian kerjasama yang dilakukan antara pemegang hak atas tanah dengan investor, yang menyatakan bahwa pemegang hak atas tanah memberikan hak kepada investor untuk mendirikan bangunan dan selama masa perjanjian Bangun, Guna, Serah (Build, Operate, Transfer/BOT) akan mengalihkan kepemilikan bangunan tersebut kepada pemegang hak atas tanah setelah masa guna waktu berakhir. ${ }^{1}$

Konsep kerjasama di lahan aset pemerintah dengan sistem Bangun, Guna, Serah (Build, Operate, Transfer/BOT) yaitu pemerintah bekerjasama dengan swasta yang adapun pembiayaan pembangunan, bisa ditanggung sebagian oleh pihak pemerintah yang dapat didanai dari Anggaran Pendapatan Belanja Negara (APBN), artinya pemerintah hanya mampu membiayai sekitar 20\% (dua puluh persen) atau lebih. Dalam hal ini pihak swasta memperoleh benefit dari pembangunan yang dilakukan oleh pihak swasta sampai dengan waktu periode tertentu, yang selanjutnya apabila waktu periode tertentu tersebut habis, maka

\footnotetext{
${ }^{1}$ Indonesia, Keputusan Menteri Keuangan Nomor Tentang Perlakuan Pajak Penghasilan Terhadap Pihak-Pihak Yang Melakukan Kerjasama Dalam Bentuk Perjanjian Bangun Guna Serah (Built Operate And Transfer). KepMenKeu No. 248/KMK.04/1995.
} 
bangunan akan diserahkan kepada pihak Pemerintah/Pemerintah Daerah dengan ketentuan: ${ }^{2}$

1. Pihak swasta melakukan pembangunan gedung komersil (seperti: rumah susun, rumah toko dan lahan parkir) dengan biaya sebagian dari pemerintah, selanjutnya bangunan diserahkan kepada pemerintah sebagai pemilik dan pengelola.

2. Pihak swasta mendapatkan bagi hasil berupa retribusi parkir dan sewa ruko masing-masing sebesar 70\% (tujuh puluh persen) dan Pemerintah 30\% (tiga puluh persen) mendapatkan dari dengan ketentuan yaitu selama 20 tahun.

3. Pemerintah mendapatkan hak mengelola aset bangunan sepenuhnya setelah masa 20 tahun.

Walker dan Smith, menjabarkan bahwa pihak yang terlibat/stakeholder yang terlibat dalam pelaksanaan kerjasama dengan sistem Bangun Guna Serah (Build Operate Transfer/BOT) meliputi: ${ }^{3}$

1. Pemerintah/Owner.

Perwakilan dari pemerintah, dalam bentuk lokal maupun pusat yang memberikan otoritas untuk menyelenggarakan pembangunan kepada pihak swasta.

2. Penerima Konsesi.

Merupakan pihak pemegang izin sebuah konsorsium dan mengambil tanggung jawab pengembangan meliputi perencanaan, pendanaan dan konstruksi, pemeliharaan serta mengoperasionalkan fasilitas atas nama Owner. Sebagai pemilik berbagai fasilitas selama masa konsesi, pemegang izin (sponsor) biasanya berbentuk perusahaan baru yang mendapatkan profit dalam investasi awal melalui penggunaan dari fasilitas tersebut.

3. Sponsor.

Pihak yang mendukung pemegang izin selama negosiasi dengan owner, dengan menjanjikan loan akan tersedia selama pengembangan proyek.

\footnotetext{
${ }^{2}$ Anjar Pachta Wirana, Tentang Aspek Hukum Perjanjian Build Operate and Transfer (BOT), (Jakarta: BPHN, 1974), hlm. 1.

${ }^{3}$ C. Walker, \& A. Smith, Privatized infrastructure: The build-operate-transfer approach, (London: Thomas Telford, 2005), hlm. 32 .
} 
Sponsor berbentuk lembaga keuangan (bank, perusahaan asuransi, bank holder) yang meminjamkan dana untuk pembangunan proyek.

4. pendana/Investor.

Pihak swasta/Investor yang menginvestasikan uangnya dalam penukaran equity. Pihak swasta/Investor ini nantinya akan mendapatkan dividen dari pelaksanaan proyek tersebut.

5. Kontraktor.

Kontraktor adalah bagian dari konsorsium dan keterlibatannya sangat central dalam model ini. Pemegang izin menugaskan kontraktor dalam pembangunan proyek. Selama pelaksanaan pembangunan proyek tersebut, kontraktor akan bertanggung-jawab dalam penggunaan subkontraktor, supplier serta konsultan.

6. Konsultan.

Pihak yang bertanggungjawab pada permasalahan desain fisik bangunan dan teknis metode kerja sehingga proyek berlangsung secara professional dan tepat waktu, biaya dan mutu.

7. Operator.

Bagian dari konsorsium yang bertanggungjawab dalam mengatur dan melayani pemegang izin dalam proses operasional fasilitas

8. Pengguna.

Merupakan pengguna layanan yang diusahakan dalam investasi ini yang menentukan tingkat occupancy.

Terkait dengan hal tersebut, maka tanah yang ada dapat dimanfaatkan dalam membangun bangunan komersil yang lebih bagus dan teratur. Mengingat keterbatasan dana yang dimiliki oleh Pemerintah sehingga diperlukan pembiayaan dari pihak swasta. Pembiayaan atau bentuk investasi dari pihak swasta maka kekurangan dalam hal pendanaan yang menjadi kendala bagi pemerintah dalam mengelola lahan tersebut dapat teratasi.

Bagi Pemerintah, pembiayaan pembangunan infrastruktur dengan mengandalkan Anggaran Pendapatan dan Belanja Negara (APBN) dirasakan semakin terbatas jumlahnya, untuk itu dibutuhkan pola-pola baru sebagai alternatif pendanaan yang tidak jarang melibatkan pihak swasta (nasional-asing) 
dalam proyek-proyek Pemerintah. ${ }^{4}$ Bentuk pendanaan selain APBN/APBD adalah pendanaan pihak swasta yang dituangkan dalam sebuah pola BOT.

Menjadi permasalahan adalah ketika kedua belah pihak yaitu Pemerintah Kota Bogor dan PT Pancakarya Grahatama Indonesia (PT PGI) telah menandatangani kesepakan perjanjian BOT untuk proyek revitalisasi terminal Baranangsiang tidak terlaksana sebagaimana yang diperjanjikan karena terhambat aturan baru yaitu Peraturan Menteri Perhubungan No.132 Tahun 2015 yang mengatakan bahwa dalam hal pengelolaan kewenangan terminal kelas A menjadi wewenang. Sebelum ada aturan tersebut, Terminal Kelas A Baranangsiang dikelola oleh Pemerintah Kota Bogor. Berdasarkan peraturan tersebut akhirnya proyek tersebut mangkrak dan berujung pada wacana Pemerintah Kota Bogor untuk membatalkan perjanjian, sedangkan menurut ketentuan yang berlaku peraturan itu tidak dapat berlaku surut. Dikeluarkannya Peraturan Menteri Perhubungan No.132 Tahun 2015 tentang Penyelenggaraan Terminal Penumpang Angkutan Jalan ${ }^{5}$ yang didasarkan pada Undang-Undang Nomor 23 Tahun 2014 tentang Pemerintahan Dalam Negeri.

Dalam Perjanjian Kerjasama BOT Nomor 601/Perj.418/ BPKAD/2012 telah diatur dengan jelas mengenai kewajiban para pihak yaitu Pihak Pemda Bogor telah sepakat menyediakan lahan untuk pembangunan yang pelaksanannya dilakukan oleh PT PGI. Namun dalam perjalannya, pihak Pemda Bogor menyalahi perjanjian yang disepakati sehingga berpotensi wanprestai dikarenakan Pemda Bogor sampai saat ini belum menyerahkan objek perjanjian kepada pihak kedua.

\section{B. Perumusan Masalah}

Berdasarkan latar belakang di atas, maka penelitian dalam skripsi ini, adalah: Apakah Pihak Pemerintah/Walikota Bogor dapat melakukan pembatalan

\footnotetext{
${ }^{4}$ Budi Santoso, Aspek Hukum Pembiayaan Proyek Infrastruktur Model BOT (Build Operate and Transfer), (Solo : Genta Press, 2008), hlm. 1.

${ }^{5}$ Peraturan Menteri Perhubungan No.132 Tahun 2015 tentang Penyelenggaraan Terminal Penumpang Angkutan Jalan, Pasal 18 Ayat (3) menegaskan bahwa rencana induk terminal ditetapkan oleh Menteri untuk terminal penumpang tipe A, Gubernur untuk terminal penumpang tipe B, Bupati/Walikota untuk terminal penumpang tipe C dan Gubernur DKI untuk terminal tipe B dan C di Ibukota Jakarta.
} 
perjanjiaan BOT secara sepihak dalam pembangunan Terminal Baranangsiang dilihat dari sudut KUHPerdata?

\section{II.PEMBAHASAN}

Untuk menjawab permasalahan penelitian ini apakah Pihak Pemerintah/ Walikota Bogor dapat melakukan pembatalan Perjanjiaan BOT secara sepihak dalam pembangunan Terminal Baranang-siang dilihat dari sudut KUHPer, maka penulis akan memaparkan beberapa fakta berupa isi perjanjian BOT antara Pemerintah Kota Bogor dengan PT PGI yang akan diuraikan ke dalam 2 (dua) sub bab dengan tujuan untuk mengetahui isi perjanjian BOT antara Pemerintah Kota Bogor dan PT PGI.

\section{A. Perjanjian BOT Proyek Revitalisasi Terminal Baranangsiang antara Pemda Bogor dan PT Pancakarya Grahatama Indonesia}

Perjanjian BOT atau Bangun Guna Serah (BGS) antara Pemerintah Kota Bogor dan PT PGI adalah perjanjian optimalisasi asset terminal Baranangsiang. Perjanjian ini ditandatangani oleh kedua belah pihak pada tanggal 29 Juni 2012. Dalam kesepakatan kerja sama proyek optimalisasi terminal Baranangsiang dengan pola perjanjian BGS dimana di dalam perjanjian tersebut Pihak Pertama yang dalam hal ini adalah Pemerintah Kota Bogor selaku pemegang kekuasaan pengelolaan barang milik daerah berupa tanah yang dikuasai seluas $21.415 \mathrm{~m}^{2}$ (dua puluh ribu satu empat ratus lima belas meter persegi) berikut bangunan di atasnya, yang dikenal umum sebagai terminal Baranangsiang, telah sepakat melakukan kerja sama dengan Pihak Kedua yaitu PT. Pancakarya Grahatama Indonesia berdasarkan berita acara hasil pelelangan Nomor 020/BA.17PAN/OTB-BGS/VI/2012 dan Keputusan Walikota Bogor Nomor 027.45-205 Tahun 2012 tentang penunjukan mitra Bangun Guna Serah (BGS) Optimalisasi aset terminal Baranangsiang Kota Bogor tanggal 25 Juni 2012, yang kemudian dituangkan kedalam Akta perjanjian Nomor: 601/Perj.418-BPKAD/2012/Nomor:005/PGI/DIR/VI/2012.

Proyek tersebut terhambat setelah dikeluarkannya Peraturan Menteri Perhubungan No.132 Tahun 2015 tentang Penyelenggaraan Terminal Penumpang 
yang mengatakan bahwa terminal kelas A menjadi wewenang Menteri di dalam pengelolaannya. ${ }^{6}$ Berdasarkan peraturan tersebut akhirnya proyek tersebut mangkrak dan berujung pada wacana Pemerintah Kota Bogor untuk membatalkan perjanjian tersebut, sedangkan menurut ketentuan yang berlaku peraturan itu tidak dapat berlaku surut. Dikeluarkannya Peraturan Menteri Perhubungan No.132 Tahun 2015 tentang Penyelenggaraan Terminal Penumpang Angkutan Jalan yang didasarkan pada Undang-Undang Nomor 23 Tahun 2014 tentang Pemerintahan Daerah.

Dengan demikian dapat dikatakan bahwa berlakunya Undang-Undang Nomor 23 Tahun 2014 tentang Pemerintahan Daerah telah mengubah penanggungjawab pengelolaan terminal tipe A hak pengelolaan menjadi urusan pemerintah pusat. Karena Undang-Undang Nomor 23 Tahun 2014 ini berlaku untuk seluruh terminal tipe A secara nasional, maka Pemkot Bogor harus patuh menyerahkan Terminal Baranangsiang secara keseluruhan.

Dalam Perjanjian Kerjasama BOT Nomor 601/Perj.418/ BPKAD/2012 telah diatur dengan jelas mengenai kewajiban para pihak yaitu Pihak Pemda Bogor telah sepakat menyediakan lahan untuk pembangunan yang pelaksanannya dilakukan oleh PT PGI Indonesia. Namun dalam perjalannya, pihak Pemda Bogor menyalahi perjanjian yang disepakati sehingga berpotensi wanprestai dikarenakan Pemdo Bogor sampai saat ini belum menyerahkan objek perjanjian kepada pihak kedua.

Pada perjanjian Nomor:601/Perj.418BPKAD/2012/Nomor:005/PGI/IR/VI/ 2012 terdiri dari 15 (lima belas) bab dan 22 (dua puluh dua) pasal yang meliputi:

1. Pasal 1 memuat tentang Maksud dan Tujuan

2. Pasal 2 mengenai Objek

3. Pasal 3 mengenai Bentuk Kerjasama

4. Pasal 4 mengenai Ruang Lingkup Umum Perjanjian

5. Pasal 5 mengenai Pembangunan

\footnotetext{
${ }^{6}$ Peraturan Menteri Perhubungan No.132 Tahun 2015 tentang Penyelenggaraan Terminal Penumpang Angkutan Jalan, Pasal 18 Ayat (3) menegaskan bahwa rencana induk terminal ditetapkan oleh Menteri untuk terminal penumpang tipe A, Gubernur untuk terminal penumpang tipe B, Bupati/Walikota untuk terminal penumpang tipe C dan Gubernur DKI untuk terminal tipe B dan C di Ibukota Jakarta.
} 
6. Pasal 6 mengenai Penyerahan Terminal

7. Pasal 7 mengenai Pemanfaatan

8. Pasal 8 mengenai Penyerahan Kawasan Perdagangan dan Jasa

9. Pasal 9 mengenai Nilai Asset dan Investasi

10. Pasal 10 mengenai Nilai Kontribusi

11. Pasal 11 mengenai Jangka Waktu

12. Pasal 12 mengenai Hak dan Kewajiban

13. Pasal 13 mengenai Larangan

14. Pasal 14 mengenai Sanksi

15. Pasal 15 mengenai Pemutusan Perjanjian

16. Pasal 16 mengenai Berakhirnya Perjanjian

17. Pasal 17 mengenai Pengawasan

18. Pasal 18 mengenai Keadaan Kahar (Force Majeur)

19. Pasal 19 mengenai Penyelesaian Perselisihan

20. Pasal 20 mengenai Pemberitahuan

21. Pasal 21 mengenai Ketentuan Lain

22. Pasal 22 mengenai Ketentuan Penutup.

Jangka waktu perjanjian ini ditetapkan selam 30 (tiga puluh) tahun terhitung sejak ditandatanganinya perjanjian tanggal 29 Juni 2012 sampai dengan 28 Juni 2042 dan dapat diperpanjang sesuai kesepakatan. Waktu pelaksanaan pembangunan dibagi dalam 3 (tiga) tahap. Tahap pembangunan terminal berikut sarana dan prasarana penunjangnya direalisasikan selesai 2 (dua) tahun, pembangunan kawasan perdagangan dan jasa berikut sarana dan prasarana penunjangnya direalisasikan 1 (satu) tahun dan tahap pemanfaatan berakhir sampai tahun 2042.

Masing-masing pihak memiliki hak dan kewajiban sebagaimana diatur dalam perjanjian dan adanya larangan untuk mengalihkan kepada pihak lain dan larangan mengubah fungsi peruntukan yang telah ditetapkan. Dalam perjanjian ini pula diatur pemutusan dan berakhirnya pekerjaan yang diakibatkan telah berakhirnya jangka waktu perjanjian, para pihak sepakat untuk mengakhiri perjanjian dan hal-hal lain yang menyebabkan objek fasilitas perjanjian musnah baik karena kebakaran atau bencana alam yang berakibat tidak dapat berfungsi 
kembali kecuali ada perbaikan dan memanfaatkannya kembali selama jangka waktu perjanjian berakhir. Investasi akan dikembalikan jika dalam pemutusan perjanjian tidak disebabkan oleh kesalahan PT PGI atau keadaan kahar (force majeur).

Keadaan kahar (force majeur) adalah setiap tindakan, peristiwa atau keadaan yang berada di luar pengendalian yang wajar dari pihak yang bersengketa dan yang tidak dapat dicegah, dihindarkan atau dijatuhi melalui tindakan ketekunan yang wajar oleh pihak tersebut yang menimbulkan dampak secara material terhadap pemenuhan kewajiban salah satu pihak. Dalam perjanjian ini, keadaan kahar meliputi namun tidak terbatas pada keadaan:

1. Setiap bentuk perang (baik diumumkan maupun tidak diumumkan), tindakan teroris atau pemberontakan;

2. Keributan umum, kerusakan, blokade, sabotase, aksi vandalisme, kerusuhan, huru-hara, konflik keagamaan, gangguan sipil atau unjuk rasa dengan kekerasan;

3. Perubahan peraturan perundang-undangan atau dokutnen tertulis lainnya yang diterbitkan oleh pemerintah, sehingga perubahan tersebut mencegah, menghaiangi, atau menunda kinerja salah satu pihak berdasarkan Penjanjian ini;

4. Ledakan, kebakaran, barjir, gempa bumi, tanah longsor, kekeringan, badai, letusan gunung berapi, angin topan, kondisi cuaca yang ekstrim, penyakit epidemik, wabah penyakit, reaksi intl atom atau bencana alain lain (Act of Good).

5. Pemogokan, pelarangan pegawai masuk keija, larangan kerja atau tindakan industni lain termasuk lindakan buruh atau pegawai Para Pihak atau dari salah satu atau seraua sub-kontraktornya;

6. Kerusakan yang tidak disengaja terhadap fasilitas atau perlengkapan lain;

7. Pengambilan, penyitaan, nasionalisasi, mobilisasi, atau pengambilan alihan seluruh atau sebagian besar proyek atau tindakan atau omisi (tindakan tidak berbuat) dari instansi pemerintah tanpa alasan yang tidak dapat dibenarkan, termasuk penghentian, penarikan, penundaan dalam memberikan atau memperbaharun perizinan; 
8. Gangguan penyediaan tenaga listrik berkepanjangan yang disebabkan oleh kegagalan dan atau kelangkaan penyediaan listrik;

9. Kecelakaan pesawat terbang atau benda-benda yang jatuh dan pesawat terbang, tekanan udara, dan dentuman supersonik termasuk dentuman yang disebabkan pesawat terbang atau alat terbang lain yang berjalan dengan kecepatan sonik atau supersonik.

Berdasarkan isi perjanjian BOT, bahwa pemutusan dan berakhirnya perjanjian dapat dilakukan dengan mengesampingkan ketentuan Pasal 1266 dan Pasal 1267 KUHPer, jika pihak kesatu memberikan 2 (tiga) kali peringatan secara tertulis dengan masing-masing jangka waktu 30 (tiga puluh) hari kalender atas penyimpangan atau pelanggaran yang dilakukan oleh pihak kedua dan pihak kedua tidak mengindahkan teguran atau peringatan tersebut berkaitan dengan pihak kedua tidak melaksanakan pembangunan sebagaimana yang diperjanjikan. Berakhirnya perjanjian dalam perjanjian BOT ini jika telah berakhir jangka waktu sebagaimana yang diperjanjikan dan jika kedua belah pihak sepakat untuk mengakhiri perjanjian serta sebab-sebab lain jika fasilitas objek perjanjian musnah sehingga tidak dapat lagi dipergunakan.

Dalam hal penyelesaian perselisihan, kedua belah pihak sepakat diselesaikan dengan musyawarah dan mufakat. Apabila perselisihan tidak dapat diselesikan secara musyawarah dan mufakat, para pihak sepakat untuk memilih domisili hukum yang tetap di wilayah hukum Pengadilan Negeri Bogor. Pada ketentuan penutup diatur hal-hal yang tidak atau belum cukup diatur dalam perjanjian seperti mengatur perjanjian tambahan (addendum) yang merupakan bagan yang tidak terpisahkan dengan perjanjian.

\section{B. Apakah Pihak Pemerintah/Walikota Bogor dapat Melakukan Pembatalan Perjanjiaan BOT secara Sepihak Dalam Pembangunan Terminal Baranangsiang Dilihat Dari Sudut KUHPer}

Pemda Kota Bogor dan PT PGI telah menekan Perjanjian revitalisasi Terminal Baranangsiang melalui sistem BOT, akan tetapi dalam perkembangannya keluar Peraturan Menteri Perhubungan No.132 Tahun 2015 tentang Penyelenggaraan Terminal Penumpang yang dalam satu pasalnya mengatur bahwa kewenangan 
pengelolaan Terminal Kelas A menjadi wewenang Pemerintah Pusat. Terminal Baranangsiang sebelumnya dikelola oleh Pemkot Bogor. Dengan adanya Peraturan Menteri Perhubungan tersebut menjadi salah satu sebab Pemkot Kota Bogor tidak kunjung melaksanakan kewajibannya memberikan izin pengosongan dan penyerahan lahan kepaa PT PGI sehingga rencana revitalisasi dan optimalisasi terminal tidak berjalan padahal kedua belah pihak telah menandatangani perjanjian yang ditandatangani oleh Walikota Diani Budiarto pada tahun 2012 dan berakhir pada tahun 2042 dengan rincian tahap pembangunan terminal berikut sarana dan prasarana penunjang harus diselesaikan paling lambat Juni tahun 2014 dan tahap pembangunan kawasan perdagangan dan jasa paling labag Juni 2015 serta tahap pemanfaatan penggunaan fasilitas tersebut sampai Juni 2042.

Dengan tidak dilaksanakannya perjanjian tersebut, jelas pihak PT PGI tidak dapat melaksanakan isi perjanjian, di satu sisi pembangunan revitalisasi dan optimalisasi terminal Baranangsiang terbengkali karena selain ada Peraturan Menteri Perhubungan dan ada penolakan dari warga dengan alasan melanggar Perda Kota Bogor Nomor 8 Tahun 2011 tentang Rencana Tata Ruang Wilayah Kota Bogor 2011-2031 dan Pasal 73 Undang-Undang Nomor 26 Tahun 2007 tentang Penataan Ruang. Selain itu, ada perbedaan pandangan Walikota Bogor yang baru mengenai desain terminal dan luas ketinggian bangunan sehingga izin pembangunan tak kunjung terbit. Di sisi lain, PT PGI telah membayar kontribusi pajak sebesar Rp.7,2 miliar ke Dinas Pendapatan Kota Bogor, dan juga telah kembali membayar kontribusi tahunan kepada Pemkot Bogor untuk melaksanakan seluruh isi ketentuan perjanjian kerja sama (PKS). Pembayaran ini sudah keempat kalinya sejak perjanjian dibuat. Bahkan PT PGI juga telah memberikan jaminan dalam bentuk performance bond senilai Rp.21,9 miliar kepada Pemkot Bogor. Selain membayar kewajiban dan kontribusi, PT PGI bahkan telah memperpanjang sewa tanah untuk Terminal Wangun sebagai terminal sementara selama proyek optimalisasi Terminal Baranangsiang berlangsung.

Sementara dalam perkembangan ketidakjelasan pelaksanaan perjanjian tersebut, rencana optimalisasi Terminal Baranangsiang yang akan diserahkan ke pemerintah pusat dengan terlebih dulu akan dilakukan pembatalan perjanjian 
antara Pemerintah Kota Bogor dengan PT PGI selaku pihak pengembang terminal, padahal dalam perjanjian terdapat klausul bahwa perjanjian ini tidak dapat dibatalkan.

Dalam perjanjian dikenal suatu asas perjanjian yaitu dikenal tiga asas yang satu dengan lainnya saling berkaitan, yakni asas konsensualisme (the principle of consensualism), asas kekuatan mengikatnya kontrak (the principle of binding force of contract), dan asas kebebasan berkontrak (the principle of freedom of contract). Asas konsensualisme ialah bahwa pada dasarnya perjanjian dan perikatan yang timbul karenanya itu sudah dilahirkan sejak detik tercapainya kesepakatan. Asas konsensualisme berkaitan dengan penghormatan martabat manusia karena dengan adanya consensus atau kesepakatan yang berasal dari perkataan seseorang maka ada kepercayaan bahwa seseorang tersebut akan memenuhinya dan perkataan seseorang yang bisa dipercaya itulah yang berkaitan dengan penghormatan terhadap martabat manusia.

Asas kebebasan berkontrak di atur dalam Pasal 1388 Ayat 1 KUH Per yang berbunyi: "Semua perjanjian yang dibuat secara sah berlaku sebagai undangundang bagi mereka yang membuatnya". Berarti bahwa para pihak diberi kebebasan untuk membuat perjanjian sesuai dengan apa yang mereka kehendaki. Berdasarkan asas tersebut para pihak bebas untuk menentukan isi perjanjian, bentuk perjanjian maupun klausula-klausula yang ada dalam perjanjian yang mereka buat. Kebebasan dalam asas kebebasan berkontrak ini adalah perwujudan dari kehendak bebas, pancaran hak asasi manusia. Perjanjian yang mereka buat mempunyai kekuatan mengikat seperti undang-undang bagi mereka yang membuatnya, (Pacta Sunt Servanda) inilah yang dimaksud dengan asas kekuatan mengikatnya kontrak, seperti diatur dalam Pasal 1338 Ayat 2 KUHPer yang berbunyi: "Suatu perjanjian tidak dapat ditarik kembali selain dengan sepakat kedua belah pihak, atau oleh karena alasan-alasan yang oleh undang-undang dinyatakan cukup untuk itu" Jadi asas tersebut menyatakan bahwa suatu perjanjian haruslah dipenuhi oleh para pihak karena perjanjian adalah undangundang bagi para pihak kecuali apabila para pihak tersebut sepakat untuk tidak memenuhi perjanjian tersebut. 
Namun kebebasan dalam asas kebebasan berkontrak bukanlah kebebasan yang tanpa batas, karena dalam ketentuan Pasal 1337 KUHPer, membatasi ketentuan Pasal 1338 KUHPer tersebut, yaitu perjanjian tidak boleh melanggar nilai-nilai, norma dan peraturan perundang-undangan yang berlaku di Indonesia. Selain itu kebebasan berkontrak Pasal 1338 KUHPer juga dibatasi syarat syahnya perjanjian yaitu sebagaimana diatur dalam pasal 1320 KUHPer bahwa untuk sahnya suatu perjanjian diperlukan empat syarat:

1. Sepakat mereka yang mengikatkan dirinya

Seseorang dikatakan telah memberikan persetujuannya/sepakat-nya (toestemming), kalau orang memang menghendaki apa yang disepakati maka sepakat sebenarnya merupakan pertemuan antara dua kehendak, dimana kehendak orang yang satu saling mengisi dengan apa yang dikehendaki pihak lain. Sedangkan dalam membuat sepakat berarti bahwa para pihak yang membuat perjanjian setuju terhadap isi perjanjian tanpa adanya tanpa adanya kekhilafan, paksaan atau peneipuan, sebagaimana diatur dalam Pasal 1321 KUH Perdata yang berbunyi: "Tidak ada sepakat yang sah apabila sepakat itu diberikan karena kekhilafan, atau diperolehnya dengan paksaan atau penipuan".

2. Kecakapan untuk membuat suatu perikatan

Dalam membuat suatu perjanjian seseorang harus cakap menurut hukum. Pasal 1321 KUH Perdata: "Setiap orang adalah untuk membuat perikatanperikatan jika oleh undang-undang tidak dinyatakan tidak cakap" Sedangkan yang menurut undang-undang dinyatakan tidak cakap diatur dalam pasal 1330 KUH Perdata: "Tak cakap untuk membuat suatu perjanjian adalah: orangorang yang belum dewasa Pasal 1330 KUH Perdata mengatur bahwa: "Belum dewasa adalah mereka yang belum mencapai umur genap 21 (dua puluh satu) tahun dan sebelumnya belum kawin" mereka yang ditaruh di bawah pengampuan. Pasal 433 KUH Per mengatur bahwa: "orang-orang yang diletakkan di bawah pengampuan adalah setiap orang yang dewasa yang selalu berada dalam keadaan dungu, sakit otak atau mata gelap dan karena keborosannya".

3. Suatu hal tertentu 
Pasal 1330 Ayat (1) KUHPer menyatakan bahwa: "Suatu perjanjian harus mempunyai sebagian pokok suatu barang yang paling sedikit ditentukan jenisnya" jadi suatu perjanjian harus mempunyai obyek dari perjanjian, barang tersebut haruslah ditentukan jenisnya" Pasal 1332 KUHPer mengatur bahwa hanya barang-barang yang dapat diperdagangkan saja yang dapat menjadi pokok dalam suatu perjanjian

4. Suatu sebab yang halal

Merupakan isi dari perjanjian, sebab itu adalah sesuatu yang menyebabkan seseorang membuat perjanjian yang termaksud. Pasal 1335 KUHPer menyatakan bahwa: "Suatu perjanjian tanpa sebab, atau yang telah dibuat karena suatu sebab yang palsu atau terlarang, tidak mempunyai kekuatan" Pasal 1336 : "Jika tidak dinyatakan sesuatu sebab, tetapi ada suatu sebab yang halal, ataupun jika ada suatu sebab lain daripada yang dinyatakan, perjanjiannya namun demikian adalah sah" Sedangkan ketentuan mengenai sebab yang halal diatur dalam Pasal 1337 KUH Per: "Suatu sebab adalah terlarang apabila dilarang oleh undang-undang, atau apabila berlawanan dengan kesusilaan baik atau ketertiban umum.”

Jadi pada dasarnya dapat ditarik kesimpulan bahwa suatu sebab yang halal berarti tidak boleh bertentangan dengan undang-undang, kesusilaan dan ketertiban umum. Syarat pertama dan kedua yaitu sepakat mereka yang mengikatkan dirinya dan kecakapan untuk membuat suatu perikatan merupakan syarat subjektif karena mengenai orang-orangnya atau subjeknya yang mengadakan perjanjian dan apabila dilanggar maka perjanjian dapat dibatalkan sedangkan syarat ketiga dan keempat tentang suatu hal tertentu dan suatu sebab yang halal merupakan syarat objektif karena mengenai objek dari perjanjian yang apabila dilanggar perjanjian akan batal demi hukum.

Perjanjian Kerjasama BOT Nomor 601/Perj.418/ BPKAD/2012 telah disepakati oleh Pemerintah Kota Bogor dan PT Pancakarya Grahatama Indonesia (PGI). Menurut Benedictus B. Nurhadi, perjanjian tersebut telah mengikat kedua belah pihak, maka sebuah perjanjian tidak dapat dibatalkan begitu saja oleh salah satu pihak, kecuali dengan cara mengajukan gugatan pembatalan perjanjian kepada pengadilan. Meskipun adanya peraturan baru yang mengalihkan 
kewenangan terminal tipe A Baranangsiang beralih menjadi kewenangan pusat, tetap perjanjian tersebut tidak dapat dibatalkan karena dalam prinsip hukum sebuah peraturan tidak dapat berlaku surut, apalagi kalau menimbulkan kerugian bagi salah satu pihak. Sebuah perjanjian baru dapat dibatalkan secara sepihak apabila tidak memenuhi Pasal 1320 KUHPer mengenai syarat sah nya sebuah perjanjian, apabila didalam sebuah perjanjian tidak memnuhi Pasal 1320 KUHPer, maka perjanjian tersebut secara otomatis dikatakan batal demi hukum. ${ }^{7}$

Hal senada juga diungkapkan Mieke Hijaya, bahwa perjanjian yang telah dibuat tidak dapat dibatalkan secara sepihak, karena di dalam perjanjian terdapat, hak dan kewajiban para pihak yang merupakan prestasi yang wajib dijalankan para pihak. Perjanjian dapat dibatalkan atas dasar kesepakatan para pihak. Pembatalan perjanjian wajib dimintakan kepada pengadilan kecuali para pihak telah sepakat untuk membatalkan perjanjian tanpa adanya putusan pengadilan terlebih dahulu. ${ }^{8}$

Berbeda dengan pendapat S. Atalim yang pada intinya menegaskan bahwa apabila Pemerintah Kota Bogor tetap menjalankan perjanjian akan berpotensi melanggar peraturan perundang-undangan dikarenakan adanya Peraturan Menteri Perhubungan No.132 Tahun 2015 tentang Penyelenggaraan Terminal Penumpang Angkutan Jalan yang merupakan ketentuan lanjutan Undang-Undang Nomor 23 Tahun 2014 tentang Pemerintahan Daerah telah mengubah penanggungjawab pengelolaan terminal tipe A ke pemerintah pusat. Apabila kontrak yang telah ada akan dilanjutkan, perlu ada upaya negosiasi antara pemeirntah Pusat, Pemerintah Kota Bogor dan pihak swasta untuk merevisi perjanjian kembali agar kedua belah pihak tidak ada yang dirugikan. ${ }^{9}$

Penulis berpendapat bahwa perjanjian BOT antara Pemerintah Kota Bogor dan PT Pancakarya Grahatama Indonesia yang telah disepakati bersama tidak dapat dibatalkan sepihak oleh Pemerintah Kota Bogor walaupun ada peraturan baru perihal kewenangan pengelolaan terminal tipe A Baranangngsing yang beralih menjadi kewenangan Pemerintah Pusat. Apapun alasannya, perjanjian yang telah

\footnotetext{
${ }^{7}$ Penulis, wawancara dengan Dr. Benedictus Bambang Nurhadi, SH, MH., selaku Komisioner Kepolisian Nasional dan Praktisi Hukum, Jakarta, 6 Mei 2018.

${ }^{8}$ Penulis, wawancara dengan Miek Hijaya, SH., MH., M.Kn., selaku Praktisi Hukum, Jakarta, 9 Mei 2018.

${ }^{9}$ Penulis, wawancara dengan Dr. S. Atalim, SH., MH., M.H., selaku Dosen Hukum Universitas Tarumanagara, Jakarta, 18 Mei 2018.
} 
disepakati tidak dapat dibatalkan kecuali ada hal-hal bertentangan dengan Pasal 1320. Mengacu asas kebebasan berkontrak di atur dalam Pasal 1338 Ayat 1 KUHPer yang menyatakan bahwa semua perjanjian yang dibuat secara sah berlaku sebagai undang-undang bagi mereka yang membuatnya.

Perjanjian dapat berakhir apabila pembatalan terhadap perjanjian yang melanggar syarat subyektif sahnya perjanjian sehingga perjanjian dapat dibatalkan, dan kedua adalah pembatalan terhadap perjanjian yang melanggar syarat obyektif perjanjian yang batal demi hukum. Akibat terhadap perjanjian yang dapat di batalkan adalah salah satu pihak dapat meminta pembatalan perjanjian. Perjanjian akan tetap mengikat para pihak apabila tidak dibatalkan oleh hakim atas permintaan pihak yang berhak meminta pembatalan. Hak untuk meminta pembatalan perjanjian, menuntut pemulihan bahkan hak untuk menuntut ganti rugi merupakan hak bagi para pihak yang merasa dirugikan, sedangkan pihak lainnya yang telah terlanjur menerima prestasi dari pihak lain wajib mengembalikannya. Sedangkan, akibat hukum terhadap perjanjian yang batal demi hukum adalah perjanjian dianggap batal atau bahkan perjanjian dianggap tidak ada dan tidak pernah terjadi dari awal. Konsekuensi lanjutan dari pembatalan perjanjian adalah apabila setelah pembatalan salah satu pihak tidak melaksanakan kewajibannya untuk mengembalikan apa yang telah diperolehnya maka pihak lain dapat mengajukan gugatan. Hal ini semata-mata untuk melaksanakan tujuan pembatalan yaitu mengembalikan keadaan sebagaimana semula sebelum perjanjian terjadi.

Adanya perubahan pengelolaan kewenangan dari Pemerintah Kota Bogor menjadi kewenangan Pusat atas terminal Baranangsiang, maka perjanjian tersebut harus tetap berjalan. Ketika kontrak sudah diteken oleh Walikota sebelumnya Diani Budiarto, maka itu berlaku sebagai hukum yang mengikat sebagaimana diatur dalam Pasal 1338 KUHPer. Kalaupun Walikota Bima Arya sekarang menyatakan tidak setuju dengan kontrak itu, maka harus dicari solusi agar pihak PT Pancakarya Grahatama Indonesia tidak dirugikan.

Secara hukum, perjanjian tersebut tidak dapat dibatalkan. Namun, secara prosedural dimungkinkan pembatalan dengan tujuan untuk pengalihan dengan alasan diserahkan ke pusat karena undang-undang menyatakan seperti itu. Dalam 
hal pengalihan badan dari daerah ke pusat, pihak pemerintah tidak dapat mengesampingkan begitu saja terhadap PT PGI karena perjanjiannya sudah mengikat dan pihak perusahaan sudah membayar nilai kontribusi guna pemenuhan perjanjian. Perjanjiannya bukan lagi antara PT PGI dengan Pemerintah Kota Bogor melainkan antara PT PGI dengan pemerintah pusat.

\section{PENUTUP}

\section{A. Kesimpulan}

Berdasarkan uraian analisis pada Bab IV di atas, maka dapat diambil kesimpulan sebagai berikut:

1. Perjanjian optimalisasi aset terminal Baranangsiang dengan pola BOT antara Pemerintah Kota Bogor dan PT PGI merupakan perjanjian yang sah dan mengikat antara kedua belah pihak dan tidak dapat dibatalkan secara sepihak oleh Pemerintah Kota Bogor, meskipun ada peraturan baru yang mengubah kewenangan terminal tipa A Baranangsiang menjadi kewenangan Pemerintah Pusat. Perjanjian dapat dibatalkan apabila melanggar Pasal 1320 KUHPer atau melanggar syarat subyektif dan obyektif sahnya perjanjian. Ketika perjanjian disepakati bersama oleh kedua belah pihak, maka perjanjian tersebut harus tetap berjalan dan berlaku sebagai hukum yang mengikat sebagaimana diatur dalam Pasal 1338 KUHPer.

\section{B. Saran}

Berdasarkan uraian kesimpulan di atas, maka saran-saran dari penulis adalah sebagai berikut:

1. Pemerintah Kota Bogor hendaknya segera memberikan kepastian kepada pihak PT Pancakarya Grahatama Indonesia agar proyek revitalisasi terminal Baranangsiang dapat segera direalisikan.

2. Perlu adanya revisi (adedendum) perjanjian antara Pemerintah Kota Bogor dengan PT Pancakarya Grahatama Indonesia terkait adanya perubahan 
kewenangan terminal tipa A Baranangsiang antara PT. PGI dengan pemerintah pusat.

\section{DAFTAR PUSTAKA}

\section{A. Buku}

Santoso, Budi. Aspek Hukum Pembiayaan Proyek Infrastruktur Model BOT (Build Operate and Transfer). (Solo: Genta Press, 2008).

Walker, C. \& A. Smith, Privatized infrastructure: The build-operate-transfer approach. (London: Thomas Telford, 2005)\.

Wirana, Anjar Pachta. Tentang Aspek Hukum Perjanjian Build Operate and Transfer (BOT). (Jakarta: BPHN, 1974).

\section{B. Peraturan Perundang-Undangan}

Indonesia, Kitab Undang-Undang Hukum Perdata

=====. Peraturan Menteri Perhubungan No.132 Tahun 2015 tentang Penyelenggaraan Terminal Penum-pang Angkutan Jalan

=====. Keputusan Menteri Keuangan Nomor Tentang Perlakuan Pajak Penghasilan Terhadap Pihak-Pihak Yang Melakukan Kerjasama Dalam Bentuk Perjanjian Bangun Guna Serah (Built Operate And Transfer).

\section{Wawancara}

Penulis, wawancara dengan Dr. Benedictus Bambang Nurhadi, SH, MH., selaku Komisioner Kepolisian Nasional dan Praktisi Hukum, Jakarta, 6 Mei 2018. 
Penulis, wawancara dengan Miek Hijaya, SH., MH., M.Kn., selaku Praktisi Hukum, Jakarta, 9 Mei 2018.

Penulis, wawancara dengan Dr. S. Atalim, SH., MH., M.H., selaku Dosen Hukum Universitas Tarumanagara, Jakarta, 18 Mei 2018. 